\title{
Pengembangan dan Validasi Kuesioner untuk Menilai Miskonsepsi tentang Pengobatan Hipertensi dan Diabetes Melitus dengan Kejadian Gagal Gijal
}

(Development and validation of a questionnaire to assess misconceptions about hypertension and diabetes mellitustreatment related to kidney failure)

\author{
Irwan Nuryana Kurniawan, Rahma Yuantari, Endang Sulistyowatiningsih, \\ Ani Khotul Faizah \& Vitarani Dwi Ananda Ningrum* \\ Universitas Islam Indonesia, JI. Kaliurang No.Km. 14,5, Krawitan, Umbulmartani, Kec. Ngemplak, Kabupaten \\ Sleman, Daerah Istimewa Yogyakarta
}

\begin{abstract}
Misconceptions become a factor in the high rate of treatment noncompliance. The public perceives medication routine for hypertension and diabetes mellitus to cause kidney failure. This study aimed to develop a valid, reliable questionnaire to assess public knowledge of misconceptions about long-term treatment of hypertension and diabetes mellitus. The questionnaire was developed in 5 stages comprising conceptualization, instrument construction, testing via Study 1 of 240 medical and non-medical students and Study 2 of 300 citizens in Sleman Regency with revised testing followed by Cronbach's alpha reliability. Meanwhile, comparing the developed questionnaire to other reliable ones for the validity tests. The knowledge scale of hypertension and diabetes treatment related to kidney failure in Study 1 and Study 2 consisted of 4 variables, including knowledge of hypertension and diabetes treatment $(\alpha 0.742, \alpha 823)$, misconceptions about medication routine $(\alpha 0.835, \alpha 0.805)$, knowledge of drugs inducing kidney failure ( $\alpha$ 0.582), ( $\alpha$ 0.581), and knowledge of kidney failure risk factors $(\alpha 0.721, \alpha 0.698)$. Such results indicated preliminary evidence and provided a valid, relevant means to assess the level of public knowledge of hypertension and diabetes long-term treatment in relation to kidney failure.
\end{abstract}

Keywords: development and validation; questionnaire; treatment misconceptions; diabetes mellitus; hypertension.

ABSTRAK: Miskonsepsi tentang pengobatan menjadi salah satu faktor tingginya ketidakpatuhan pengobatan. Masyarakat beranggapan bahwa penggunaan obat rutin pada hipertensi dan diabetes mellitus (DM) dapat menyebabkan gagal ginjal. Penelitian ini bertujuan untuk menyediakan kuesioner valid dan reliabel yang dapat digunakan untuk mengukur miskonsepsi masyarakat tentang pengobatan jangka panjang pada hipertensi dan DM dengan kejadian gagal ginjal. Pengembangan kuesioner dilakukan dalam 5 tahap yakni konseptualisasi, konstruksi alat ukur, uji coba melalui studi 1 pada 240 mahasiswa/i medis dan non-medis, dan studi 2 pada 300 masyarakat di wilayah Kabupaten Sleman, tes revisi dan selanjutnya tahap analisis melalui uji reliabilitas alpha cronbach. Sementara itu, uji validitas dilakukan dengan membandingkan kuesioner ini dengan kuesioner terpercaya lainnya. Hasil skala pengetahuan tentang terapi hipertensi dan DM terkait kejadian gagal ginjal pada studi 1 dan studi 2 tersusun atas 4 variabel pengetahuan meliputi: pengetahuan terapi hipertensi dan DMT $(\alpha 0.742, \alpha 823)$, miskonsepsi penggunaan obat rutin $(\alpha 0.835$, $\alpha$ 0.805), pengetahuan obat penyebab gagal ginjal ( $\alpha$ 0.582), ( $\alpha$ 0.581), serta pengetahuan faktor risiko gagal ginjal ( $\alpha 0.721, \alpha$ 0.698). Hasil analisis ini menunjukkan bukti awal dan penyediaan instrumen valid dan relevan untuk mengukur tingkat miskonsepsi masyarakat tentang pengobatan jangka panjang pada hipertensi dan DM terkait dengan gagal ginjal.

Kata kunci: pengembangan dan validasi; kuesioner; miskonsepsi pengobatan; diabetes melitus; hipertensi.

\section{Pendahuluan}

Peningkatan kejadian penyakit komplikasi akibat DM atau hipertensi berupa gagal ginjal, stroke, dan penyakit jantung meningkat pada 5 tahun terakhir dengan besaran persentase masing-masing 1,8\%, 3,9\%, dan $8,3 \%$, berturutan pada tahun 2018. Hal ini diduga kuat akibat penggunaan obat yang tidak rutin karena sebagian besar pasien merasa sudah sehat setelah mengkonsumsi obat yang diresepkan, baik pada pasien DM (50,4\%) maupun hipertensi $(59,8 \%)$ [1]. Demikian halnya yang ditemukan pada penelitian ketidakpatuhan obat di beberapa negara, termasuk ketidakpatuhan pada penebusan resep pertama (primary medication nonadherence/

\section{Article history}

Received: 10 April 2020 Accepted: 05 Okt 2020 Published: 30 Des 2020

Access this article

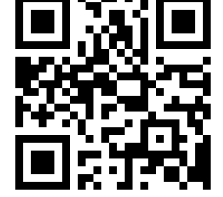


PMN) obat antidiabetes [2], termasuk insulin [3]. Selain itu, ketidakpatuhan dengan menggunakan parameter tidak menebus kembali resep dalam 180 hari berikutnya, juga ditunjukkan pada pengobatan hipertensi [4]. Hal ini juga dikonfirmasi pada penelitian dengan melibatkan 646 pasien yang menunjukkan penyakit kardiovaskular, termasuk hipertensi, menjadi salah satu prediktor ketidakpatuhan obat paska menjalani rawat inap [5]. Meskipun telah diketahui dari beberapa penelitian, pengendalian glikemik maupun tekanan darah yang buruk dapat meningkatkan kejadian penyakit komplikasi yang berdampak fatal [6-8], namun permasalahan ketidakpatuhan pengobatan jangka panjang pada penyakit kronik masih menjadi masalah di berbagai negara. Dengan demikian, peningkatan pengetahuan untuk mencegah atau menurunkan miskonsepsi penggunaan obat jangka panjang menjadi penting untuk dilakukan. Untuk itu, diperlukan kuisioner yang dapat menilai tingkat miskonsepsi penggunaan obat jangka panjang sebagai upaya awal identifikasi kebutuhan penyediaan materi edukasi yang sesuai untuk menekan penyakit komplikasi pada DM maupun hipertensi melalui kepatuhan penggunaan obat.

Beberapa penelitian pengembangan kuisioner untuk menilai pengetahuan tentang penyakit tidak menular, termasuk hipertensi, DM, dan gagal ginjal telah dilakukan pada beberapa penelitia [9-12]. Kuisioner yang dikembangkan tersebut termasuk kuisoner untuk menilai keyakinan tentang pengobatan yang terbukti berkorelasi dengan kepatuhan penggunaan obat dan memiliki reliabilitas serta validitas yang baik [13]. Selain mayoritas ditujukan untuk pasien, kuisioner tersebut tidak bersifat spesifik berkaitan dengan tingkat miskonsepsi penggunaan obat jangka panjang terkait dengan kejadian gagal ginjal. Oleh karena itu, penelitian ini melakukan pengembangan dan validasi kuisioner untuk menilai tingkat miskonsepsi masyarakat tentang penggunaan obat rutin untuk penyakit hipertensi dan DM tipe 2 yang merupakan kategori penyakit tidak menular tertinggi di berbagai negara, termasuk di Indonsia.

\section{Metode Penelitian}

\section{Tahap Pengembangan Kuisioner}

Penelitian pengembangan kuesioner dilakukan melalui 5 tahap yaitu test conceptualization, test construction, test try-out, test analysis, dan test revision di wilayah Kabupaten Sleman, Propinsi DIY. Test conceptualization dilakukan melalui penggalian literatur terpercaya terkait miskonsepsi

Tabel 1. Deskripsi subjek penelitian studi 1

\begin{tabular}{llc}
\hline \multicolumn{1}{c}{ Faktor } & \multicolumn{1}{c}{ Kategori } & $\mathbf{n}(\%)$ \\
\hline Jenis kelamin & Laki-laki & $83(34,6)$ \\
& Perempuan & $157(65,4)$ \\
Kategori pendidikan & Medis & $127(52,9)$ \\
& Non-Medis & $113(47,1)$ \\
Penyakit yang dialami & Tidak Ada & $207(86,3)$ \\
Riwayat penyakit & Lain-lain & $33(13,7)$ \\
& Tidak Ada & $175(72,9)$ \\
& Gagal Ginjal & $1(0,4)$ \\
Riwayat penyakit keluarga & Lain-lain & $64(26,7)$ \\
& Tidak Ada & $185(77,2)$ \\
& Hipertensi & $12(5,0)$ \\
& DM & $20(8,3)$ \\
& Gagal Ginjal & $2(0,8)$ \\
& HT-DM & $2(0,8)$ \\
& HT-GG & $1(0,4)$ \\
& Lain-lain & $18(7,5)$ \\
\hline
\end{tabular}

HT-DM hipertensi dan diabetes mellitus

HT-GG hipertensi dan gagal ginjal 
Tabel 2. Deskripsi subjek penelitian studi 2

\begin{tabular}{|c|c|c|}
\hline Faktor & Kategori & n (\%) \\
\hline \multirow[t]{2}{*}{ Jenis kelamin } & Laki-laki & $97(32,3)$ \\
\hline & Perempuan & $203(67,7)$ \\
\hline \multirow[t]{7}{*}{ Usia (tahun) } & $\leq 25$ & $35(11,7)$ \\
\hline & $26-35$ & $93(31,0)$ \\
\hline & $36-45$ & $79(26,3)$ \\
\hline & $46-55$ & $62(20,7)$ \\
\hline & $56-65$ & $23(7,7)$ \\
\hline & $\geq 66$ & $1(0,3)$ \\
\hline & Tidak Mengisi & $7(2,3)$ \\
\hline \multirow[t]{8}{*}{ Pekerjaan } & PNS & $64(21,4)$ \\
\hline & Wiraswasta & $42(14,0)$ \\
\hline & Karyawan & $30(10,0)$ \\
\hline & Mahasiswa/i & $19(6,3)$ \\
\hline & $\mathrm{IRT}$ & $67(22,4)$ \\
\hline & Buruh & $46(15,3)$ \\
\hline & Lain-lain & $7(2,3)$ \\
\hline & Tidak Mengisi & $25(8,3)$ \\
\hline \multirow[t]{5}{*}{ Penyakit yang dialami } & Hipertensi & $5(1,7)$ \\
\hline & DM & $3(1,0)$ \\
\hline & Gagal Ginjal & $0(0)$ \\
\hline & Lain-lain & $28(9,3)$ \\
\hline & Tidak Ada & $264(88,0)$ \\
\hline \multirow[t]{5}{*}{ Riwayat penyakit } & Hipertensi & $2(0,7)$ \\
\hline & DM & $2(0,7)$ \\
\hline & Gagal Ginjal & $0(0)$ \\
\hline & Lain-lain & $23(7,6)$ \\
\hline & Tidak Ada & $273(91,0)$ \\
\hline \multirow[t]{6}{*}{ Riwayat penyakit keluarga } & Hipertensi & $16(5,3)$ \\
\hline & DM & $10(3,3)$ \\
\hline & Gagal Ginjal & $2(0,7)$ \\
\hline & HT-DM & $2(0,7)$ \\
\hline & Lain-lain & $10(3,3)$ \\
\hline & Tidak Ada & $260(86,7)$ \\
\hline
\end{tabular}

HT-DM hipertensi-diabetes melitus

pengobatan dari beberapa sumber. Materi tersebut selanjutnya digunakan dalam tahap konstruksi alat ukur dengan menyusun blueprint melalui proses FGD (Focus Group Disscusion) yang melibatkan 2 apoteker bidang farmasi klinik, 1 dokter bidang patologi klinik, dan 1 pakar psikometri. Blueprint ini digunakan sebagai acuan dalam pembuatan items pertanyaan pada kuesioner. Domain pengetahuan dalam kuesioner ini mencakup terapi hipertensi dan DMT2, miskonsepsi penggunaan obat rutin, obat-obat yang dapat menyebabkan gagal ginjal dan faktor risiko gagal ginjal. Melalui FGD diperoleh 19 items pertanyaan terbuka (open-ended question) yaitu responden memberikan jawaban berdasarkan yang diketahuinya. Untuk pemberian skor pada setiap jawaban dari masing- 


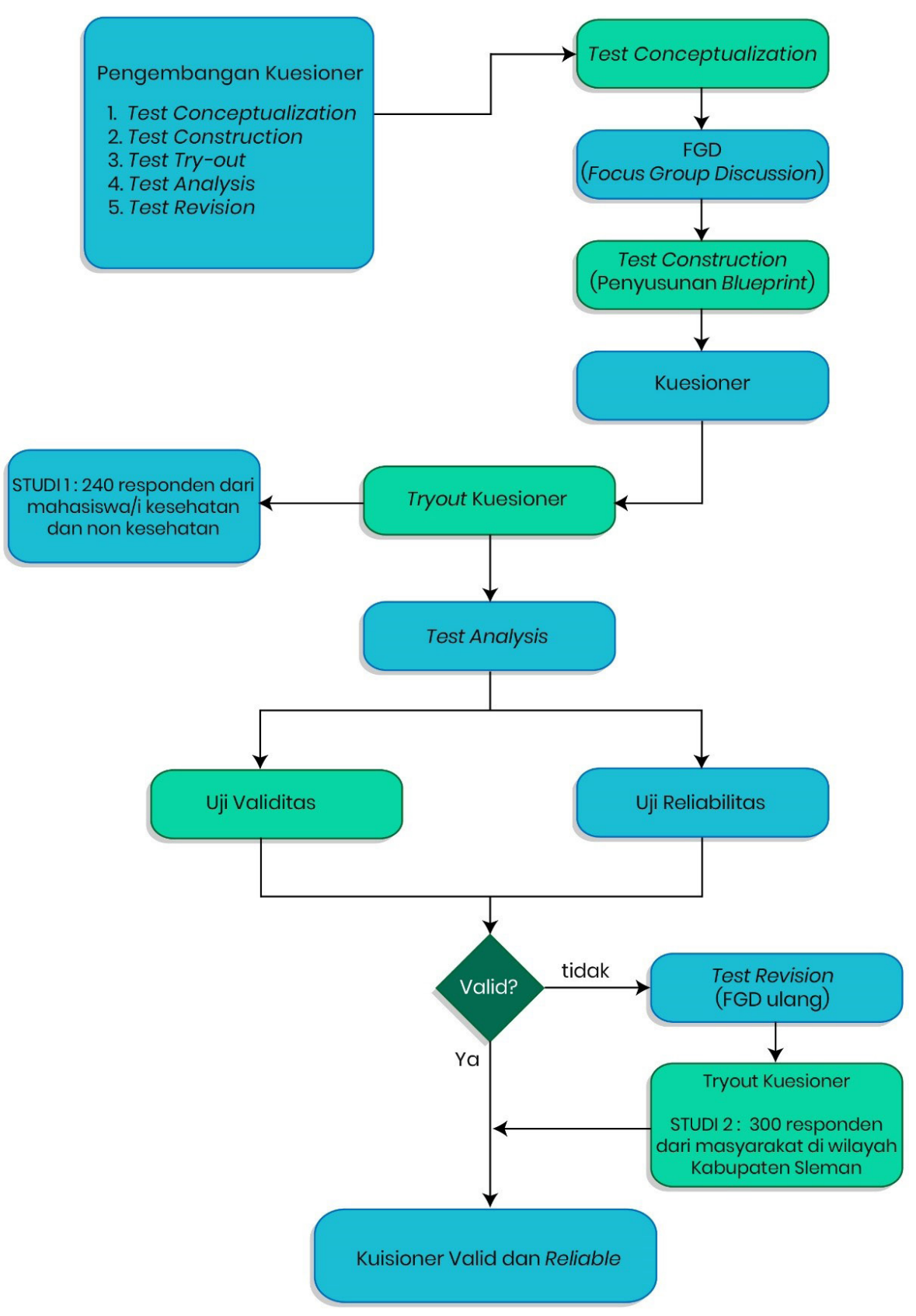

Gambar 1. Desain penelitian pengembangan dan validasi kuisioner

masing items pertanyaan Bagian A, B, C dan D disesuaikan pada kunci jawaban yang sebelumnya telah ditetapkan dalam forum FGD. Deskripsi besaran skor untuk masingmasing item pertanyaan dalam kuesioner menjadi bagian dalam supplementary files. Selanjutnya, tes try out melalui 2 studi yang melibatkan 540 responden, yakni studi 1 melibatkan 240 mahasiswa/i medis dan non-medis, dan studi 2 pada 300 masyarakat di wilayah tempat penelitian.

\section{Uji Validitas Kuisioner}

Sementara itu, uji validitas dilakukan dengan membandingkan kuesioner yang dikembangkan dengan kuesioner lain yaitu Medication Morisky Adherence Scale-8 (MMAS-8) yang diuji menggunakan analisis korelasi parsial dengan mengendalikan faktor Social Desirability. Selain itu, penambahan penggunaan kuisioner pembanding yakni Your Health and Well-Being Questionnaire pada studi 2 dan uji reliabilitas menggunakan Alpha Cronbach. 


\section{Uji Etik Penelitian}

Penelitian ini telah lolos kaji etik dari Komite Etik Fakultas Kedokteran Universitas Islam Indonesia dengan nomor protokol 14/Ka.Kom.Et/70/KE/VIII. Secara skematis, tahapan penelitian tertera pada Gambar 1.

\section{Hasil dan Diskusi}

Penelitian ini melibatkan lebih dari 540 responden yakni 240 mahasiswa/i medis dan non medis dengan rata-

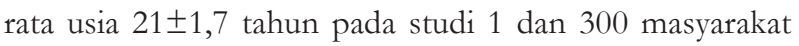
kabupaten Sleman propinsi Daerah Istimewa Yogyakarta pada studi 2 pada rentang tahun 2017-2019. Meskipun tidak ada formula baku jumlah sampel yang dilibatkan dalam validasi kuisoner [14] namun melibatkan sampel dalam jumlah besar menjadi rekomendasi yang lebih baik dalam meningkatkan kualitas perolehan data [15]. Data demografi subjek penelitian masing-masing pada studi 1 dan studi 2 tertera pada Tabel 1 dan Tabel 2 , berturutturut.

Responden penelitian pada studi 1 terutama melibatkan mahasiswa/i yang sedang menempuh pendidikan bidang kesehatan, baik responden maupun pihak keluarga inti tidak memiliki riwayat penyakit kronik. Kelompok responden yang sedang menempuh jenjang pendidikan tinggi dinilai memiliki pengetahuan dan kemampuan yang memadai untuk dapat mencermati, menilai dan mengkritisi muatan kuisioner yang dikembangkan sehingga menjadi subjek terpilih pada studi 1. Hal ini penting untuk dilakukan dalam penelitian pengembangan dan validasi kusioner untuk mendapatkan masukan untuk pengembangan items kuisioner yang lebih baik [16]. Sementara itu, studi 2 yang melibatkan responden yang berjumlah lebih banyak, yakni masyarakat Kabupaten Sleman, wilayah dengan jumlah penduduk terbanyak di Propinsi DIY, yang memiliki berbagai keragaman karakter demografi, menjadi kelompok terpilih pada studi 2 .
Demikian halnya pada studi 1 , kategori responden perempuan merupakan kategori jenis kelamin terbanyak yang ditemukan pada studi 2 dengan rentang usia yakni antara 26 - 35 tahun dan merupakan ibu rumah tangga. Keterlibatan jumlah responden dalam jumlah besar dengan keragaman karakter demografi, selain dapat menyediakan perolehan data yang mewakili kondisi masyarakat yang akan dinilai tingkat miskonsepsinya menggunakan kuisoner ini $[15,16]$, juga dapat memberikan masukan yang diperlukan dalam tahap revisi pengembangan kuisioner. Selanjutnya, untuk menilai sejauhmana hasil pengukuran tingkat miskonsepsi pengetahuan penggunaan obat dapat dipercaya, dilakukan uji reliabilitas kuisiner baik pada studi 1 maupun 2 dengan hasil tertera pada Tabel 3.

Tabel 3. menunjukkan, baik pada studi 1 maupun studi 2, memiliki koefisien reliabilitas dan indeks diskriminasi yang dinilai mumpuni sebagai kuisoner yang reliabel. Peningkatan perolehan kedua indikator tersebut juga membuktikan bahwa test revision yang dilakukan memberikan dampak yang baik dalam meningkatkan kualitas kuisioner yang dikembangkan. Revisi dilakukan dalam forum FGD dengan melibatkan baik ahli psikometri, farmasis klinik, maupun dokter. Demikian pula ketika pada studi 2 digunakan skala your health well-being menunjukkan koefisien reliabilitas alpha cronbach 0,836 (12 items) dengan indeks diskriminasi 0,176-0,661.

Selain itu, analisis faktor eksploratori dilakukan untuk menemukan adanya kemungkinan faktor yang menyusun items tersebut untuk membentuk sebuah pola yang mendasari sebuah variabel. Hal ini bertujuan agar mampu mengungkap pengetahuan masyarakat tentang terapi jangka panjang pada hipertensi dan diabetes melitus terkait kejadian gagal ginjal melalui penggunaan Principal Axis Factor (PAF). Hasil studi 1 menunjukkan terdapat 19 items yang terdapat dalam kuesioner ini yang terbagi menjadi 6 dimensi. Sementara itu, hasil studi 2 menunjukkan dari 19 items yang terdapat dalam kuesioner ini terdapat 1 item

Tabel 3. Deskripsi subjek penelitian studi 1

\begin{tabular}{|c|c|c|c|c|}
\hline \multirow{2}{*}{ Dimensi } & \multicolumn{2}{|c|}{ koefisien reliabilitas (alpha cronbach $\alpha$ ) } & \multicolumn{2}{|c|}{ indeks diskriminasi items } \\
\hline & Studi 1 & Studi 2 & Studi 1 & Studi 2 \\
\hline Pengetahuan terapi hipertensi dan diabetes melitus & 0,742 (4 items) & 0,823 (4 items) & $0,464-0,599$ & $0,610-0,696$ \\
\hline Miskonsepsi penggunaan obat rutin & 0,835 (8 items) & 0,805 (8 items) & $0,472-0,765$ & $0,415-0,594$ \\
\hline Pengetahuan obat yang menyebabkan gagal ginjal & 0,582 (5 items) & 0,581 (5 items) & $0,211-0,493$ & $0,990-0,454$ \\
\hline Pengetahuan faktor risiko gagal ginjal & 0,721 (2 items) & 0,698 (2 items) & 0,580 & 0,561 \\
\hline Kepatuhan obat & 0,735 (8 items) & 0,615 (8 items) & $0,064-0,626$ & $0,017-0,471$ \\
\hline Social desirability & 0,730 (11 items) & 0,753 (11 items) & $0,110-0,536$ & $0,269-0,567$ \\
\hline
\end{tabular}


Tabel 4. Inter-factor correlation skala pengetahuan terapi hipertensi dan diabetes melitus terkait kejadian gagal ginjal pada kedua studi

\begin{tabular}{|c|c|c|c|c|c|c|c|c|}
\hline \multirow{3}{*}{ Dimensi } & \multirow{2}{*}{\multicolumn{2}{|c|}{$\begin{array}{c}\begin{array}{c}\text { Terapi hipertensi } \\
\text { diabetes melitus }\end{array} \\
\text { studi }\end{array}$}} & \multicolumn{2}{|c|}{$\begin{array}{c}\text { Miskonsepsi penggunaan } \\
\text { obat rutin }\end{array}$} & \multicolumn{2}{|c|}{$\begin{array}{l}\text { Obat penyebab } \\
\text { gagal ginjal }\end{array}$} & \multicolumn{2}{|c|}{$\begin{array}{l}\text { Faktor risiko } \\
\text { gagal ginjal }\end{array}$} \\
\hline & & & & & & & & \\
\hline & 1 & 2 & 1 & 2 & 1 & 2 & 1 & 2 \\
\hline $\begin{array}{l}\text { Terapi hipertensi-diabe- } \\
\text { tes melitus }\end{array}$ & 1,000 & 1,000 & 0,546 & 0,524 & 0,355 & 0,248 & 0,435 & 0,378 \\
\hline $\begin{array}{l}\text { Miskonsepsi penggunaan } \\
\text { obat rutin }\end{array}$ & 0,546 & 0,524 & 1,000 & 1,000 & 0,530 & 0,456 & 0,572 & 0,406 \\
\hline Obat penyebab gagal ginjal & 0,355 & 0,248 & 0,530 & 0,456 & 1,000 & 1,000 & 0,455 & 0,438 \\
\hline Faktor risiko gagal ginjal & 0,435 & 0,378 & 0,572 & 0,406 & 0,455 & 0,438 & 1,000 & 1,000 \\
\hline
\end{tabular}

yang tidak masuk dalam dimensi, sehingga terdapat 18 items yang terbagi menjadi 6 dimensi. Faktor- faktor tersebut merupakan faktor dengan kategori dapat dinterpretasikan (interpretable) pada setiap dimensinya.

Selanjutnya faktor-faktor tersebut dianalisis baik pada studi 1 maupun 2 yang menghasilkan 6 faktor dengan dimensi terbaik pada studi 2 yakni : Faktor I sebagai dimensi Terapi HDM sebesar 29,104\%; Faktor II dengan dimensi tujuan pengobatan HDM dengan persentase sebesar 39,585\%, Faktor III dengan dimnesi Pengetahuan obat penyebab gagal ginjal dengan peresentase sebesar $48,558 \%$, Faktor IV domensi kepatuhan obat dengan persentase sebesar 57,151\%; Faktor $\mathrm{V}$ dengan dimensi miskonsepsi penggunaan obat rutin dengan persentase sebesar 63,797\%, dan selanjutnya fakto VI dengan dimensi faktor risiko ggal ginjal dengan persentase sebesar 69,476\%. Setelah terbentuk faktor-faktor baru, maka selanjutnya dilakukan pengujian korelasi antar faktor seperti tertera pada Tabel 4.

Berdasarkan pada analisis faktor pada Tabel 4., hasil interfactor correlation, korelasi yang dimunculkan pada 4 dimensi Skala Pengetahuan Terapi Hipertensi dan Diabetes Melitus Terkait Kejadian Gagal Ginjal berkisar pada studi 1 dan 2 masing-masing antara 0,355 - 1 dan 0,248 - 1, berturutan. Korelasi dengan kisaran angka yang moderat hingga moderat tinggi tersebut mendukung adanya dimensi yang beragam pada Skala Pengetahuan Terapi Hipertensi dan Diabetes Melitus Terkait Kejadian Gagal Ginjal. Hal ini menunjukkan bahwa individu yang menjadi responden penelitian dapat membedakan 4 dimensi dari Skala Pengetahuan Terapi Hipertensi dan Diabetes Melitus Terkait Kejadian Gagal Ginjal. Korelasi moderat antar faktor Skala Pengetahuan Terapi Hipertensi dan Diabetes Melitus Terkait Kejadian Gagal Ginjal menunjukkan bahwa dimensi-dimensi tersebut memiliki korelasi, namun masing-masing dari dimensi memiliki perbedaan. Dimensi-dimensi yang terbentuk merupakan kompenen pengetahuan mendasar yang diperlukan untuk dapat menilai tingkat miskonsepsi pengetahuan masyarakat mengenai penggunaan obat. Pengetahuan terapi hipertensi dan DM menjadi bagian pengetahuan yang perlu diberikan edukasi untuk masyarakat dalam intervensi komprehensif terutama untuk kelompok pasien dengan penyakit tidak menular seperti DM dan hipertensi [17]. Sebagian besar pasien menunjukkan pengetahuan rendah terkait penatalaksanaan penyakitnya [18], terutama di negara dengan pendapatan rendah-sedang seperti di Indonesia. Demikian halnya dengan pengetahuan penggunaan obat rutin, mayoritas pasien dengan salah satu atau kedua penyakit tersebut menghendaki adanya penghentian obatnya untuk sementara waktu akibat kondisinya yang tidak lagi merasakan keluhan yang berarti (merasa sehat) [19]. Konsepsi seperti ini memicu ketidakpatuhan penggunaan obat yang dapat menyebabkan kejadian penyakit komplikasi. Hingga saat ini, masih banyak masyarakat yang beranggapan menggunakan obat dalam jangka waktu lama merupakan penyebab kejadian gagal ginjal. Kurangnya pengetahuan mengenai jenis obat, besaran dosis, durasi penggunaan obat menjadikan edukasi terkait hal tersebut menjadi penting untuk dilakukan baik sebagai strategi pencegahan kejadian gagal ginjal maupun pengendalian penyakit predisposisi gagal ginjal seperti DM dan hipertensi [20]. Selain keterbatasan aspek pengetahuan tersebut, pengetahuan kontrol glikemik dan tekanan darah yang baik merupakan strategi efektif dalam penurunan faktor risiko kejadian gagal ginjal juga masih rendah $[21,22]$. Hal ini penting untuk ditindaklanjuti sebagai program promosi kesehatan yang efektif sehingga dapat menekan kejadian gagal ginjal [23] seperti yang telah dilakukan oleh tim peneliti (data tidak ditampilkan). Hal ini seiring dengan temuan penelitian bahwa pasien yang telah terdiagnosis baik DM maupun hipertensi [24] maupun 
Tabel 5. Korelasi prediktor dan kriteria variabel

\begin{tabular}{lccc}
\hline & \multicolumn{1}{c}{$\begin{array}{c}\text { Skala Kepatuhan Berobat } \\
\text { Skala Pengetahuan Terapi Hipertensi dan } \\
\text { Diabetes Melitus Terkait Kejadian Gagal Ginjal }\end{array}$} & $\begin{array}{c}\text { Skala Your Health Well- } \\
\text { Being Questionnaire* }\end{array}$ \\
\cline { 2 - 4 } & $\mathbf{1}$ & $\mathbf{2}$ & $\mathbf{2}$ \\
\hline Pengetahuan Terapi HDM & $-0,005$ & 0,075 & 0,271 \\
Miskonsepsi Penggunaan Obat Rutin & 0,167 & 0,144 & 0,305 \\
Pengetahuan Obat Penyebab Gagal Ginjal & 0,049 & 0,173 & 0,071 \\
Pengetahuan Faktor Risiko Gagal Ginjal & 0,171 & 0,154 & 0,086 \\
\hline
\end{tabular}

* penambahan kuisioner ini dalam uji validasi kuisioner yang dikembangkan hanya dilakukan pada studi 2 berdasarkan hasil FGD dengan ahli

yang sudah berkomplikasi menjadi penyakit gagal ginjal dengan berbagai tingkat keparahan penyakitnya (tahap 1-5), memiliki tingkat kewaspadaan yang rendah [25].

Sementara itu, untuk mengetahui validitas konkruen dan konvergen yang terdapat pada skala Pengetahuan kuisoner yang dikembangkan, peneliti menguji hubungan antara skor total dan dimensi faktornya dengan skor total dan dimensi-dimensi pada skala Kepatuhan Berobat (Morisky Medication Adherence Scale MMAS-8) menggunakan analisis korelasi parsial dengan mengendalikan faktor social desirability. MMAS-8 menjadi kuisioner terpilih sebagai instrumen pembanding karena telah banyak digunakan pada berbagai penelitian pengukuran kepatuhan dan menunjukkan tingkat reliabilitas dan validitas yang baik yang telah diterjemahkan ke beragam bahasa, termasuk bahasa Indonesia [26]. Hasil korelasi prediktor dan kriteria variabel menggunakan MMAS-8 tertera pada Tabel 5 .

Hasil analisis korelasional merupakan hasil isian responden yang memenuhi syarat skor menggunakan instrumen social desirability, sehingga hasil yang diperoleh merupakan hasil analisis dari subjek yang tidak memiliki kecenderungan untuk melakukan konformitas terhadap streotip sosial disekitarnya. Hasil penelitian menunjukan nilai Kaiser Mayer-Olkin Measure of Sampling sebesar 0,834. dengan demikian memenuhi persyaratan KMO karena memiliki nilai > 0,500. Sementara itu, perolehan nilai Barlett's Test of Sphericity sebesar 1831,445 dengan signifikansi sebesar 0,000. Dengan demikian perolehan nilai Barlett's Test of Sphericity memenuhi persyaratan karena signifikansi kurang dari 0,05 (5\%). Sementara itu, selain skala kuisioner MMAS-8, uji validasi pada studi 2 menggunakan skala Your Health Well-Being dengan menggunakan analisis korelasi parsial yang juga dengan mengendalikan faktor social desirability (Tabel 5).

Seperti halnya pada uji validasi studi 1, pada uji studi 2 menunjukkan nilai Kaiser Mayer-Olkin (KMO)
Measure of Sampling sebesar 0,776 yang bermakna memenuhi persyaratan karena memiliki nilai lebih dari 0,500. Sementara nilai Barlett's Test of Sphericity sebesar 2358,045 dengan signifikansi sebesar 0,000 yang juga bermakna memenuhi persyaratan karena signifikansi kurang dari 0,05 (5\%). Oleh karena itu, berdasarkan perolehan indikator-indikator tersebut, penelitian ini telah menunjukkan bukti awal properti psikometrik (struktur faktor, reliabilitas, dan validitas konvergen) yang cukup memadai sebagai instrumen untuk mengukur menilai miskonsepsi tentang pengobatan jangka panjang pada hipertensi dan diabetes mellitus terkait dengan kejadian gagal ginjal. Selanjutnya, sebagai bagian dari program pengabdian masyarakat berbasis penelitian, kuisioner ini digunakan sebagai instrumen pengetahuan kader posbindu untuk membandingkan efektivitas beragam model edukasi (data tidak ditampilkan).

\section{Kesimpulan}

Adanya korelasi pada skala pembanding dengan Skala Pengetahuan penggunaan obat jangka panjang pada pasien DM dan hipertensi menunjukkan bahwa kuesioner yang telah disusun ini valid.

\section{Ucapan Terima Kasih}

Terimakasih kepada Kemenristek-Dikti RI yang telah membiayai sebagian pelaksanaan penelitian berbasis pengabdian masyarakat melalui hibah Pengabdian Masyarakat IbM No. 017/Rek/80/DPPM/IbMKEMENRISTEKDIKTI dengan judul program "Penguatan Peran Posbindu Puskesmas dalam Penurunan Miskonsepsi Masyarakat tentang Penggunaan Obat Rutin sebagai Penyebab Gagal Ginjal. 


\section{Referensi}

[1]. Kementerian Kesehatan Badan Penelitian dan Pengembangan Kesehatan. Hasil Utama Riskesdas 2018 [Internet]. Kemenkes RI. 2019 [cited 13 February 2020]. Available from: https://www.kemkes. go.id/resources/download/info-terkini/hasil-riskesdas-2018.pdf

[2]. da Costa FA, Pedro AR, Teixeira I, Bragança F, da Silva JA, Cabrita J. Primary non-adherence in Portugal: findings and implications. Int J Clin Pharm 2015;37:626-35. https://doi.org/10.1007/s11096015-0108-1.

[3]. Karter AJ, Subramanian U, Saha C, Crosson JC, Parker MM, Swain $\mathrm{BE}$, et al. Barriers to Insulin Initiation: The Translating Research Into Action for Diabetes Insulin Starts Project. Diabetes Care 2010;33:733-5. https://doi.org/10.2337/dc09-1184.

[4]. Raebel MA, Carroll NM, Ellis JL, Schroeder EB, Bayliss EA. Importance of Including Early Non-adherence in Estimations of Medication Adherence. Ann Pharmacother 2011;45:1053-60. https://doi. org/10.1345/aph.1Q146.

[5]. TPaasche-Orlow MK, Shaykevich S, Cohen MJ, Cohen MJ, Cawthon C, Schnipper JL, et al. Predictors of medication adherence postdischarge: The impact of patient age, insurance status, and prior adherence. Journal of Hospital Medicine 2012;7.

[6]. Tun NN, Arunagirinathan G, Munshi SK, Pappachan JM. Diabetes mellitus and stroke: A clinical update. World J Diabetes 2017;8:23548. https://doi.org/10.4239/wid.v8.i6.235.

[7]. Petrie JR, Guzik TJ, Touyz RM. Diabetes, Hypertension, and Cardiovascular Disease: Clinical Insights and Vascular Mechanisms. Can J Cardiol 2018;34:575-84. https://doi.org/10.1016/i. cjca.2017.12.005.

[8]. Ningrum VDA, Ikawati Z, Sadewa AH, Ikhsan MR. Kontrol Glikemik dan Prevalensi Gagal Ginjal Kronik pada Pasien Diabetes Melitus Tipe 2 di Puskesmas Wilayah Provinsi DIY Tahun 2015. Indonesian Journal of Clinical Pharmacy 2017;6:78-90. https://doi.org/10.15416/ ijcp.2017.6.2.78.

[9]. Chamroonsawasdi K, Chottanapund S, Tunyasitthisundhorn P, Phokaewsuksa N, Ruksujarit T, Phasuksathaporn P. Development and Validation of a Questionnaire to Assess Knowledge, Threat and Coping Appraisal, and Intention to Practice Healthy Behaviors Related to Non-Communicable Diseases in the Thai Population. Behav Sci (Basel) 2017;7. https://doi.org/10.3390/bs7020020

[10]. Eigenmann C, Skinner T, Colagiuri R. Development and validation of a diabetes knowledge questionnaire. Pract Diab Int 2011;28:166170d. https://doi.org/10.1002/pdi.1586.

[11]. Wright JA, Wallston KA, Elasy TA, Ikizler TA, Cavanaugh KL. Development and Results of a Kidney Disease Knowledge Survey Given to Patients With CKD. Am J Kidney Dis 2011;57:387-95. https://doi.org/10.1053/j.ajkd.2010.09.018.

[12]. Devins GM, Binik YM, Mandin H, Letourneau PK, Hollomby DJ, Barre $P E$, et al. The Kidney Disease Questionnaire: a test for measuring patient knowledge about end-stage renal disease. J Clin Epidemiol 1990;43:297-307.

[13]. Horne R, Weinman J, Hankins M. The beliefs about medicines questionnaire: The development and evaluation of a new method for assessing the cognitive representation of medication. Psychology \& Health 1999;14:1-24. https://doi. org/10.1080/08870449908407311.
[14]. Osborne J, Costello A. Sample size and subject to items ratio in principal components analysis. Practical Assessment, Research, and Evaluation 2019;9. https://doi.org/10.7275/ktzq-jq66.

[15]. Tsang S, Royse CF, Terkawi AS. Guidelines for developing, translating, and validating a questionnaire in perioperative and pain medicine. Saudi J Anaesth 2017;11:S80-9. https://doi.org/10.4103/sja. SJA_203_17.

[16]. Kelley K, Clark B, Brown V, Sitzia J. Good practice in the conduct and reporting of survey research. Int J Qual Health Care 2003;15:261-6. https://doi.org/10.1093/intahc/mzg031.

[17]. Correia JC, Lachat S, Lagger G, Chappuis F, Golay A, Beran D, et al. Interventions targeting hypertension and diabetes mellitus at community and primary healthcare level in low- and middle-income countries:a scoping review. BMC Public Health 2019;19:1542. https://doi.org/10.1186/s12889-019-7842-6.

[18]. Moosa A, Bezuidenhout S, Meyer JC, Godman B. Knowledge regarding medicines management of type 2 diabetes amongst patients attending a Community Health Centre in South Africa. Journal of Pharmaceutical Health Services Research 2019;10:13-28. https://doi.org/10.1111/iphs.12283.

[19]. Adams OP, Carter AO. Knowledge, attitudes, practices, and barriers reported by patients receiving diabetes and hypertension primary health care in Barbados: a focus group study. BMC Family Practice 2011;12:135. https://doi.org/10.1186/1471-2296-12-135.

[20]. Ghane Shahrbaf F, Assadi F. Drug-induced renal disorders. J Renal Inj Prev 2015;4:57-60. https://doi.org/10.12861/jrip.2015.12.

[21]. Roomizadeh P, Taheri D, Abedini A, Mortazavi M, Larry M, Mehdikhani $B$, et al. Limited knowledge of chronic kidney disease and its main risk factors among Iranian community: an appeal for promoting national public health education programs. Int J Health Policy Manag 2014;2:161-6. https://doi.org/10.15171/ijhpm.2014.37.

[22]. Alvis Zibran M, Mohammadnezhad M. Management of Type 2 Diabetes and Chronic Kidney Disease in Fiji in 2018: Knowledge, Attitude, and Practice of Patients. Rev Diabet Stud 2019;15:26-34. https://doi.org/10.1900/RDS.2019.15.26.

[23]. Collins AJ, Gilbertson DT, Snyder JJ, Chen S-C, Foley RN. Chronic kidney disease awareness, screening and prevention: rationale for the design of a public education program. Nephrology (Carlton) 2010;15 Suppl 2:37-42. https://doi.org/10.1111/j.14401797.2010.01312.x.

[24]. Kumela Goro K, Desalegn Wolide A, Kerga Dibaba F, Gashe Fufa F, Wakjira Garedow A, Edilu Tufa B, et al. Patient Awareness, Prevalence, and Risk Factors of Chronic Kidney Disease among Diabetes Mellitus and Hypertensive Patients at Jimma University Medical Center, Ethiopia. Biomed Res Int 2019;2019. https://doi. org/10.1155/2019/2383508.

[25]. Hwang S-J, Tsai J-C, Chen H-C. Epidemiology, impact and preventive care of chronic kidney disease in Taiwan. Nephrology (Carlton) 2010;15 Suppl 2:3-9. https://doi.org/10.1111/i.14401797.2010.01304.x.

[26]. Vika V, Siagian M, Wangge G. Validity and reliability of Morisky Medication Adherence Scale 8 Bahasa version to measure statin adherence among military pilots. Health Science Journal of Indonesia 2016;7:129-133-133. https://doi.org/10.22435/hsji. v7i2.5343.129-133. 